Supporting Information

\title{
Visible Light and Glutathione Dually Responsive Delivery of Polymer-Conjugated Temozolomide Intermediate for Glioblastoma Chemotherapy
}

\author{
Ke Du, ${ }^{\dagger}$ Qiuyu Xia, ${ }^{\dagger}$ Jian Sun, ${ }^{,+}$and Fude Feng ${ }^{*}{ }^{\prime}$
}

$\dagger$ Key Laboratory of High Performance Polymer Material and Technology of Ministry of Education, Department of Polymer Science \& Engineering, School of Chemistry \& Chemical Engineering, Nanjing University, Nanjing 210023, China

†Current address: Key Laboratory of Organic Solids, Institute of Chemistry Chinese Academy of Sciences, Beijing 100190, China

*Corresponding author: E-mail: fengfd@nju.edu.cn 


\section{Synthesis of MA3}

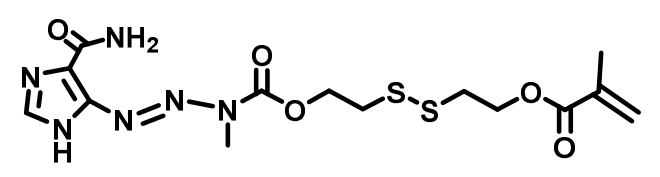

MTIC and 2-((2-(((4-nitrophenoxy)carbonyl)oxy)ethyl)disulfanyl)ethyl methacrylate (MA1) were synthesized following the previously reported procedure. ${ }^{1,2}$ To prepare MA3, MTIC (84 mg, $0.5 \mathrm{mmol})$, TEA (101 mg, $1 \mathrm{mmol}$ ), and MA1 (290 $\mathrm{mg}, 0.75 \mathrm{mmol}$ ) were suspended in anhydrous N,N-Dimethylformamide (DMF, $5 \mathrm{~mL}$ ). The reaction solution changed from turbid to completely clear orange after stirring at room temperature for $36 \mathrm{~h}$ under argon. The reaction process was monitored by thinlayer chromatography (TLC). The crude product was purified by column chromatography on silica gel $(\mathrm{DCM} / \mathrm{MeOH}, \mathrm{v} / \mathrm{v}=30: 1)$ to provide a white solid (82 mg, 38\%). ${ }^{1} \mathrm{H}$ NMR (400 MHz, $\left.\mathrm{CDCl}_{3}, 298 \mathrm{~K}\right) \delta(\mathrm{ppm}): 8.19$ (s, 1H), 6.13 (s, 1H), 5.59 (t, 1H), $4.64(\mathrm{t}, 2 \mathrm{H}), 4.43(\mathrm{t}, 2 \mathrm{H}), 3.44(\mathrm{~s}, 3 \mathrm{H}), 3.10(\mathrm{t}, 2 \mathrm{H}), 3.02(\mathrm{t}, 2 \mathrm{H}), 1.94(\mathrm{~s}, 3 \mathrm{H})$; ${ }^{13} \mathrm{C} \mathrm{NMR}\left(100 \mathrm{MHz}, \mathrm{CDCl}_{3}, 298 \mathrm{~K}\right) \delta$ (ppm): 167.16, 161.48, 153.57, 147.25, 137.65, $135.98,126.12,118.94,65.52,62.52,37.22,36.68,30.89,18.30$. MA3, Q-TOF MS $m / z:[\mathrm{M}+\mathrm{Na}]^{+}$calcd: 439.0829. Found: $[\mathrm{M}+\mathrm{Na}]^{+}=439.0829$.

\section{Synthesis of MA4}<smiles>C=C(C)C(=O)OCCOC(=O)N(C)/N=N/c1[nH]cnc1C(N)=O</smiles>

MTIC (84 mg, $0.5 \mathrm{mmol})$, TEA (101 mg, $1 \mathrm{mmol}$ ), and HEMA-imidazole (MA2) ${ }^{3}$ (134 mg, $0.6 \mathrm{mmol}$ ) were suspended in anhydrous DMF $(5 \mathrm{~mL})$. The reaction was then stirred at room temperature for $12 \mathrm{~h}$ under argon. The reaction process was monitored by thin-layer chromatography (TLC). The crude product was purified by column chromatography on silica gel $(\mathrm{DCM} / \mathrm{MeOH}, \mathrm{v} / \mathrm{v}=30: 1)$ to provide a white solid (56 mg, 35\%). ${ }^{1} \mathrm{H}$ NMR (400 MHz, $\left.\mathrm{CDCl}_{3}, 298 \mathrm{~K}\right) \delta(\mathrm{ppm}): 8.08$ (s, 1H), 6.05 (s, 1H), 5.51 (s, 1H), $4.59(\mathrm{~m}, 2 \mathrm{H}), 4.44(\mathrm{~m}, 2 \mathrm{H}), 3.41(\mathrm{~s}, 3 \mathrm{H}), 1.85(\mathrm{~s}, 3 \mathrm{H}) ;{ }^{13} \mathrm{C} \mathrm{NMR}(100 \mathrm{MHz}$, $\left.\mathrm{CDCl}_{3}, 298 \mathrm{~K}\right) \delta(\mathrm{ppm}): 165.27,159.41,151.64,145.20,135.19,133.84,124.45$, 
116.33, 63.55, 60.23, 28.83, 16.31. MA4, Q-TOF MS m/z: $[\mathrm{M}+\mathrm{H}]^{+}$calcd: 325.1255 . Found: $[\mathrm{M}+\mathrm{H}]^{+}=325.1263$.

\section{Synthesis of POEGMA}

To a $10 \mathrm{~mL}$ flask was added OEGMA (300 mg, $1 \mathrm{mmol}$ ), ACVA (5.6 mg, $0.02 \mathrm{mmol}$, and CPADB (28 mg, $0.1 \mathrm{mmol}$ ) in anhydrous DMSO. The mixture was degassed using argon for $30 \mathrm{~min}$ then stirred at $70{ }^{\circ} \mathrm{C}$ for $24 \mathrm{~h}$. The polymerization was quenched by immersion of the reaction flask into frozen liquid ethanol $\left(-30^{\circ} \mathrm{C}\right)$ and exposure to air. The polymer was obtained after precipitation into excess pre-cooled diethyl ether and three times of repeated precipitation process (yield 89.3\%). ${ }^{1} \mathrm{H} \mathrm{NMR}\left(400 \mathrm{MHz}, \mathrm{CDCl}_{3}\right.$, $298 \mathrm{~K}) \delta$ (ppm): 7.30-7.94 (CHCHCHCHCHC of benzene ring), 4.24-3.34 $\left(\mathrm{OCH}_{2} \mathrm{CH}_{2} \mathrm{O}, \mathrm{OCH}_{3}\right.$ of the OEG group), 2.08-1.66 $\left(\mathrm{CH}_{2}\right.$ of the polymer backbone), $1.13-0.78\left(\mathrm{CH}_{3}\right.$ of the polymer backbone).

\section{Synthesis of diblock copolymer P1}

A mixture of POEGMA (250 mg, $0.025 \mathrm{mmol})$, MA3 (104 mg, $0.25 \mathrm{mmol})$, and ACVA (1.4 mg, $0.005 \mathrm{mmol})$ was dissolved by anhydrous DMSO (1 mL) in a $10 \mathrm{~mL}$ flask. The mixture was degassed with argon for $30 \mathrm{~min}$ and stirred at $70{ }^{\circ} \mathrm{C}$ for $48 \mathrm{~h}$. The polymerization was quenched by immersion of the reaction flask into frozen liquid ethanol $\left(-30^{\circ} \mathrm{C}\right)$ and exposure to air. The polymer was obtained by precipitation into excess pre-cooled diethyl ether and three times of repeated precipitation process (yield 52.3\%). ${ }^{1} \mathrm{H} \mathrm{NMR}\left(400 \mathrm{MHz}, \mathrm{CDCl}_{3}, 298 \mathrm{~K}\right) \delta(\mathrm{ppm}): 7.31-8.16(\mathrm{CHCHCHCHCHC}$ of the benzene ring, $\mathrm{CH}$ of the imidazole), $4.79-3.94\left(\mathrm{COOCH}_{2}\right.$ of the side chain), 4.30-3.34 $\left(\mathrm{OCH}_{2} \mathrm{CH}_{2} \mathrm{O}, \mathrm{OCH}_{3}\right.$ of the OEG group, $\left.\mathrm{NCH}_{3}\right), 3.28-2.87\left(\mathrm{SSCH}_{2}\right)$, $2.08-1.66\left(\mathrm{CH}_{2}\right.$ of the polymer backbone $), 1.13-0.78\left(\mathrm{CH}_{3}\right.$ of the polymer backbone).

\section{Synthesis of diblock copolymer P2}

A mixture of POEGMA (150 mg, 0.015), MA4 (50 mg, $0.15 \mathrm{mmol})$, and ACVA (2.8 $\mathrm{mg}, 0.01 \mathrm{mmol})$ was dissolved by anhydrous DMSO $(1 \mathrm{~mL})$ in a $10 \mathrm{~mL}$ flask. The mixture was degassed with argon for $30 \mathrm{~min}$ then stirred at $70{ }^{\circ} \mathrm{C}$ for $48 \mathrm{~h}$. The workup 
process was similar to P1 with an isolated yield of $31.5 \%$. ${ }^{1} \mathrm{H} \mathrm{NMR}\left(400 \mathrm{MHz}, \mathrm{CDCl}_{3}\right.$, $298 \mathrm{~K}) \delta$ (ppm): 7.31-8.16 (CHCHCHCHCHC of the benzene ring, $\mathrm{CH}$ of the imidazole), 4.78-3.93 (COOCH2 of the side chain), 4.30-3.34 (OCH2CH2O, OCH3 of the OEG group, $\mathrm{NCH} 3), 2.08-1.66$ (CH2 of the polymer backbone), 1.13-0.78 (CH3 of the polymer backbone).

\section{Synthesis of rhodamine B sulfonyl chloride (SRB-Cl)}

SRB-Cl was synthesized following the procedure described earlier with minor modifications. ${ }^{4}$ In brief, sulforhodamine B (200 mg, $\left.0.35 \mathrm{mmol}\right)$ was dissolved in anhydrous dichloromethane $(10 \mathrm{~mL})$ and cooled to $0{ }^{\circ} \mathrm{C}$ with an ice-water bath. Oxalyl chloride $(160 \mu \mathrm{L}, 1.89 \mathrm{mmol})$ and DMF ( $6 \mu \mathrm{L})$ were dripped slowly into the flask. The reaction mixture was allowed naturally warm to room temperature and stirred overnight. Toluene was added and the reaction solvent was removed in vacuo. The residue was precipitated with ether, washed multiple times with ethyl acetate, and dried in vacuo to obtain SRB-Cl a dark red solid (172 mg, 83\%). ${ }^{1} \mathrm{H}$ NMR (400 MHz, DMSO-d 6 , $298 \mathrm{~K}$ ) $\delta(\mathrm{ppm}): 8.28(\mathrm{~s}, 1 \mathrm{H}), 7.74(\mathrm{~d}, 1 \mathrm{H}), 7.17(\mathrm{~d}, 1 \mathrm{H}), 7.03(\mathrm{~s}, 4 \mathrm{H}), 6.92(\mathrm{~s}, 2 \mathrm{H}), 3.63(\mathrm{q}$, $8 \mathrm{H}), 1.21(\mathrm{t}, 12 \mathrm{H})$.

\section{Synthesis of sulforhodamine B-cystamine (SRB-NH2)}

SRB-NH$H_{2}$ was synthesized following the procedure reported previously. ${ }^{5} \mathrm{SRB}-\mathrm{Cl}$ (100 mg, $0.17 \mathrm{mmol}$ ) was dissolved in $10 \mathrm{~mL}$ of anhydrous DMF and cooled to $0{ }^{\circ} \mathrm{C}$. Cystamine dihydrochloride (149 mg, $0.66 \mathrm{mmol})$ and triethylamine $(280 \mu \mathrm{L}, 2 \mathrm{mmol})$ in $10 \mathrm{~mL}$ DMF were added slowly to the solution. The mixture was stirred at room temperature for $3 \mathrm{~h}$ and then at $-20{ }^{\circ} \mathrm{C}$ for another $16 \mathrm{~h}$. The reaction process was monitored by TLC. The crude product was purified by column chromatography on silica gel $\left(\mathrm{MeCN} / \mathrm{CHCl}_{3} / \mathrm{MeOH}, \mathrm{v} / \mathrm{v}=30: 30: 2\right.$ to $\left.12: 0: 1\right)$ to provide a dark red solid (33 mg, 28\%). ${ }^{1} \mathrm{H}$ NMR (400 MHz, MeOD-d, $\left.298 \mathrm{~K}\right) \delta(\mathrm{ppm}): 8.66$ (s, 1H), 8.14 (d, 1H), $7.56(\mathrm{~d}, 1 \mathrm{H}), 7.16-6.92(\mathrm{~m}, 6 \mathrm{H}), 3.68(\mathrm{q}, 8 \mathrm{H}), 3.37(\mathrm{t}, 2 \mathrm{H}), 3.01(\mathrm{~m}, 2 \mathrm{H}), 2.91(\mathrm{~m}$, 2H), $2.70(\mathrm{t}, 2 \mathrm{H}), 1.31(\mathrm{t}, 12 \mathrm{H})$. 


\section{Synthesis of Rhop1}

SRB-NH$H_{2}$ was cleaved with dithiothreitol and catalytic amounts of DMAP after stirring overnight. The crude product was purified by quickly column chromatography $(\mathrm{DCM} / \mathrm{MeOH}, \mathrm{v} / \mathrm{v}=15: 1)$ to obtain SRB-SH. The product was immediately subjected to the next reaction due to the poor stability.

The SRB-labeled polymer was prepared through the thiol/disulfide exchange reaction. SRB-SH was added to the solution of P1. The mixture was degassed using argon for $30 \mathrm{~min}$ and stirred at room temperature overnight, followed by solvent removal in vacuo and purification by size exclusion chromatography (SEC) using S$\mathrm{X} 1$ beads (Bio-beads) with THF as the eluent to obtain ${ }^{\text {Rho }} \mathrm{P} 1 .{ }^{\text {Rho }} \mathrm{P} 1 \mathrm{NP}$ was prepared after self-assembly of ${ }^{\text {Rhop} 1 ~ i n ~ w a t e r . ~}$ 


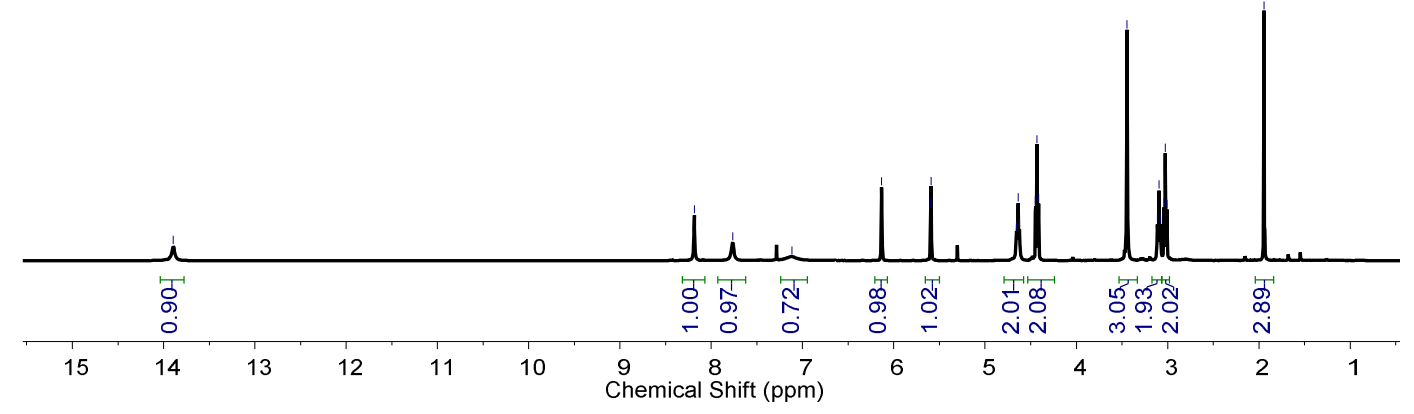

Figure S1. ${ }^{1} \mathrm{H}$ NMR spectrum of MA3 in $\mathrm{CDCl}_{3}$.

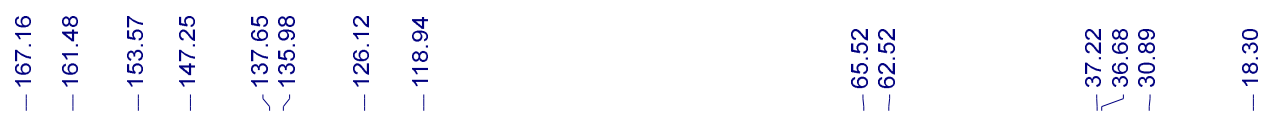

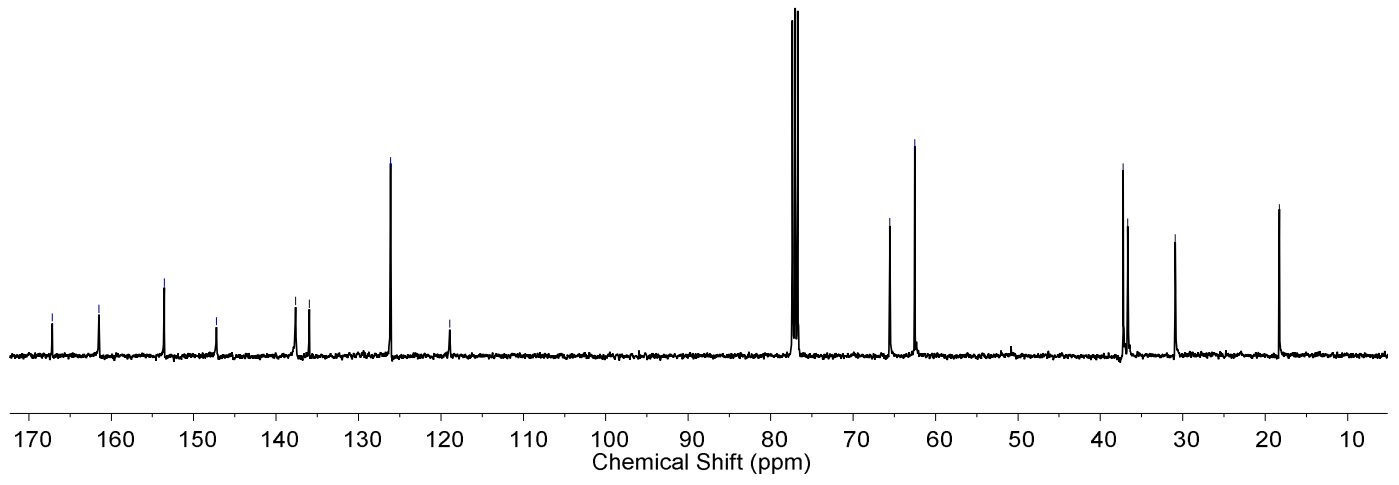

Figure S2. ${ }^{13} \mathrm{C}$ NMR spectrum of MA3 in $\mathrm{CDCl}_{3}$. 


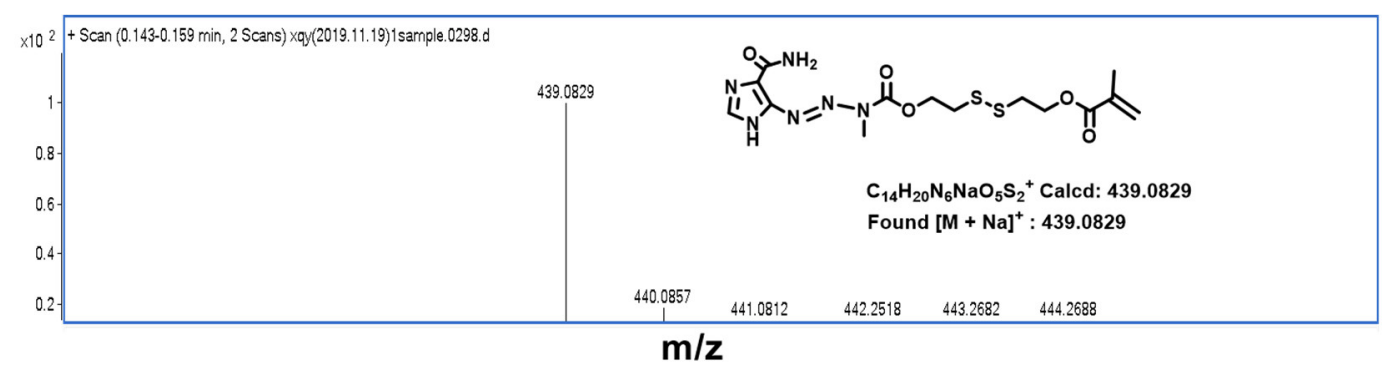

Figure S3. Q-TOF LC/MS spectrum of MA3.

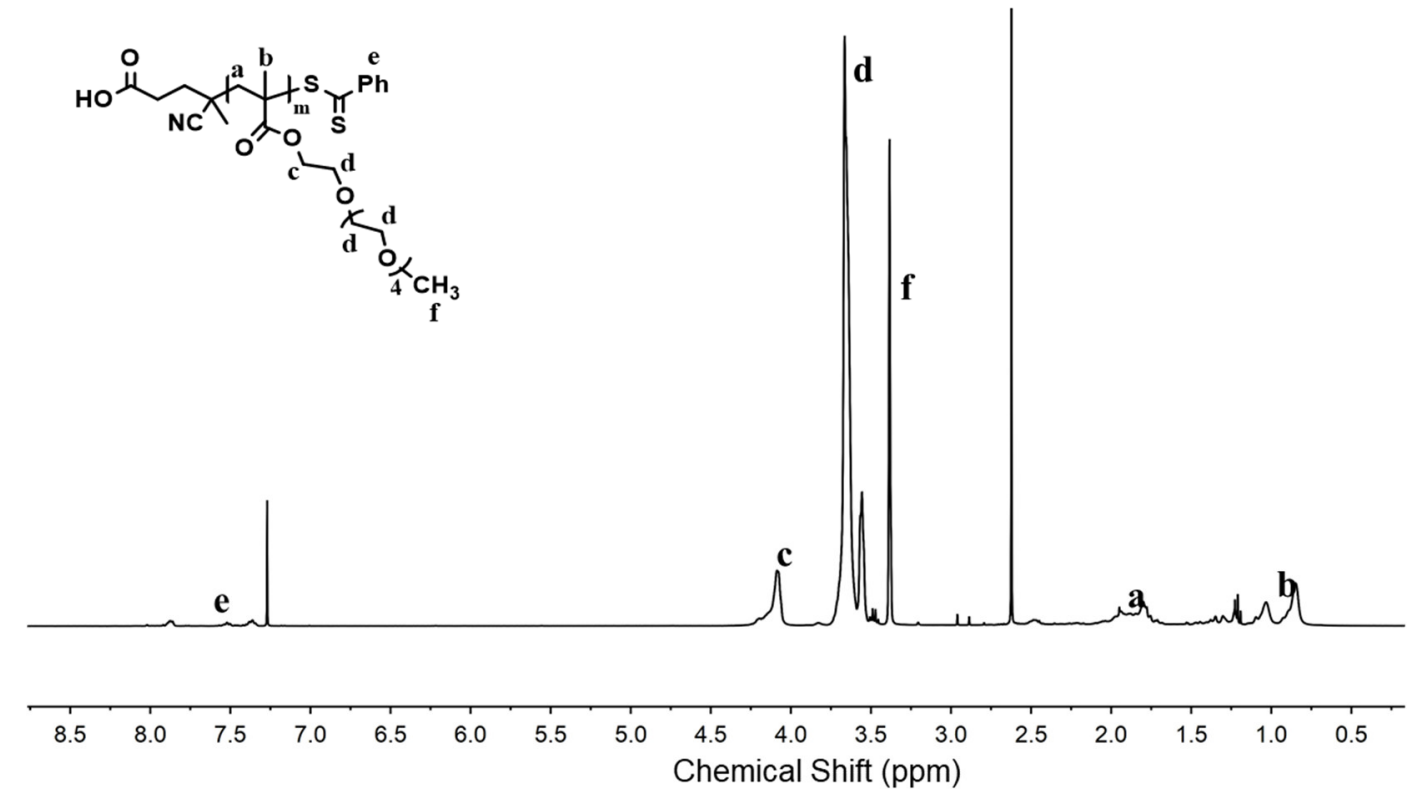

Figure S4. ${ }^{1} \mathrm{H}$ NMR spectrum of POEGMA in $\mathrm{CDCl}_{3}$.

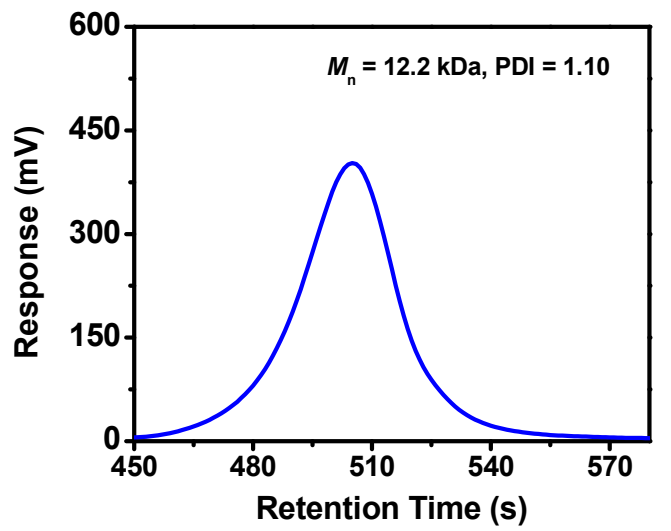

Figure S5. GPC traces of POEGMA. 


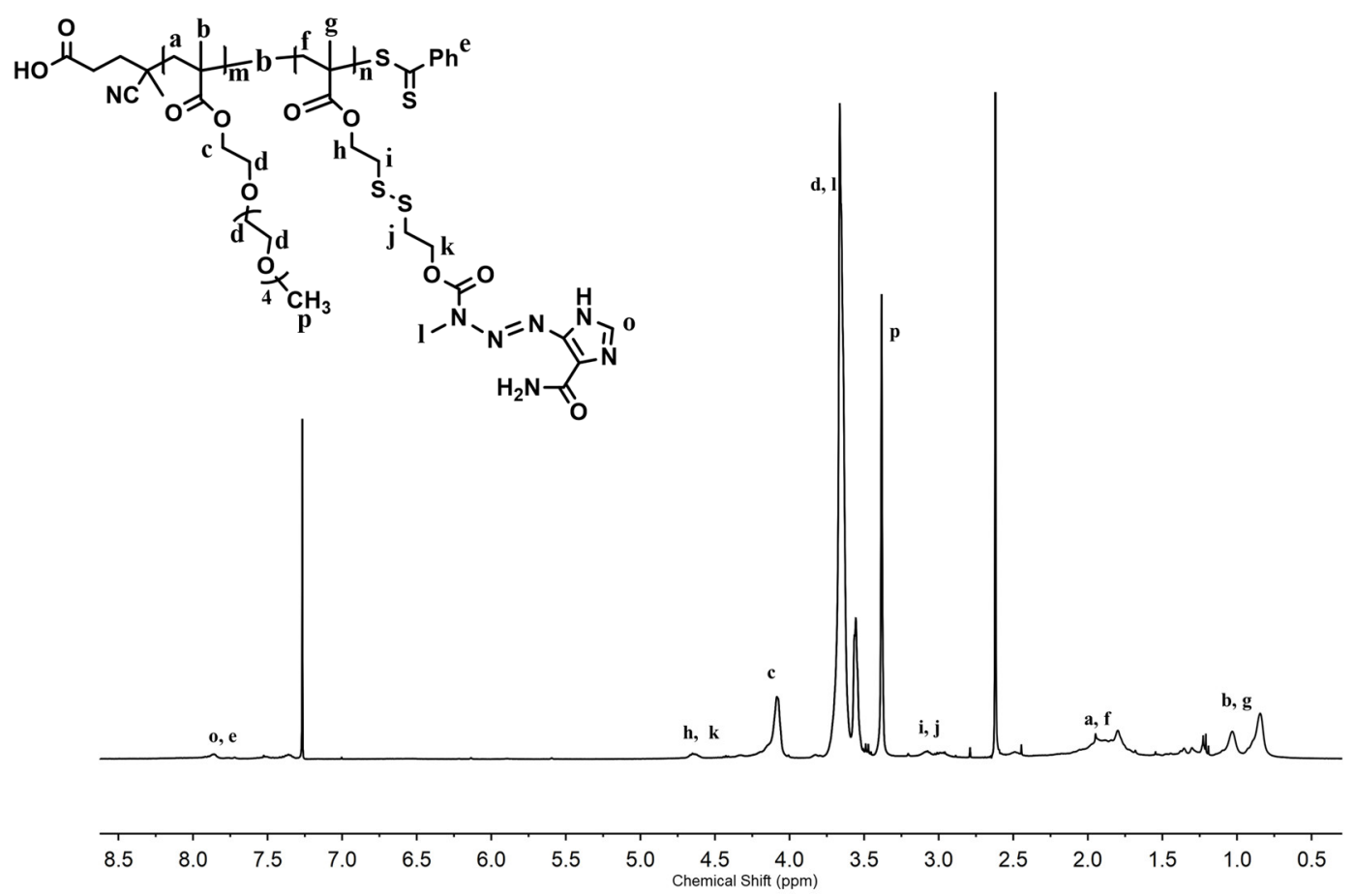

Figure S6. ${ }^{1} \mathrm{H}$ NMR spectrum of $\mathrm{P} 1$ in $\mathrm{CDCl}_{3}$.
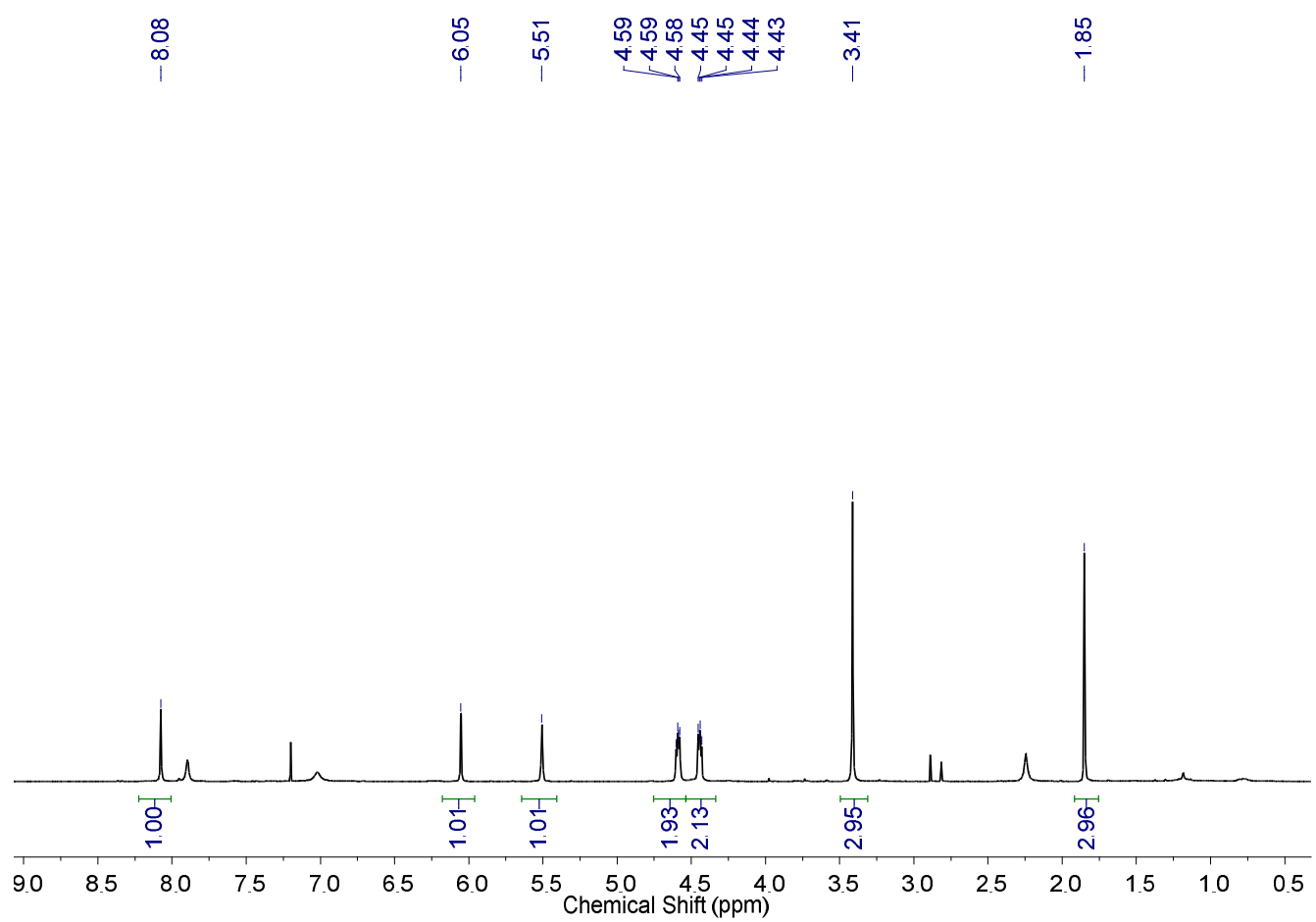

Figure S7. ${ }^{1} \mathrm{H}$ NMR spectrum of MA4 in $\mathrm{CDCl}_{3}$. 


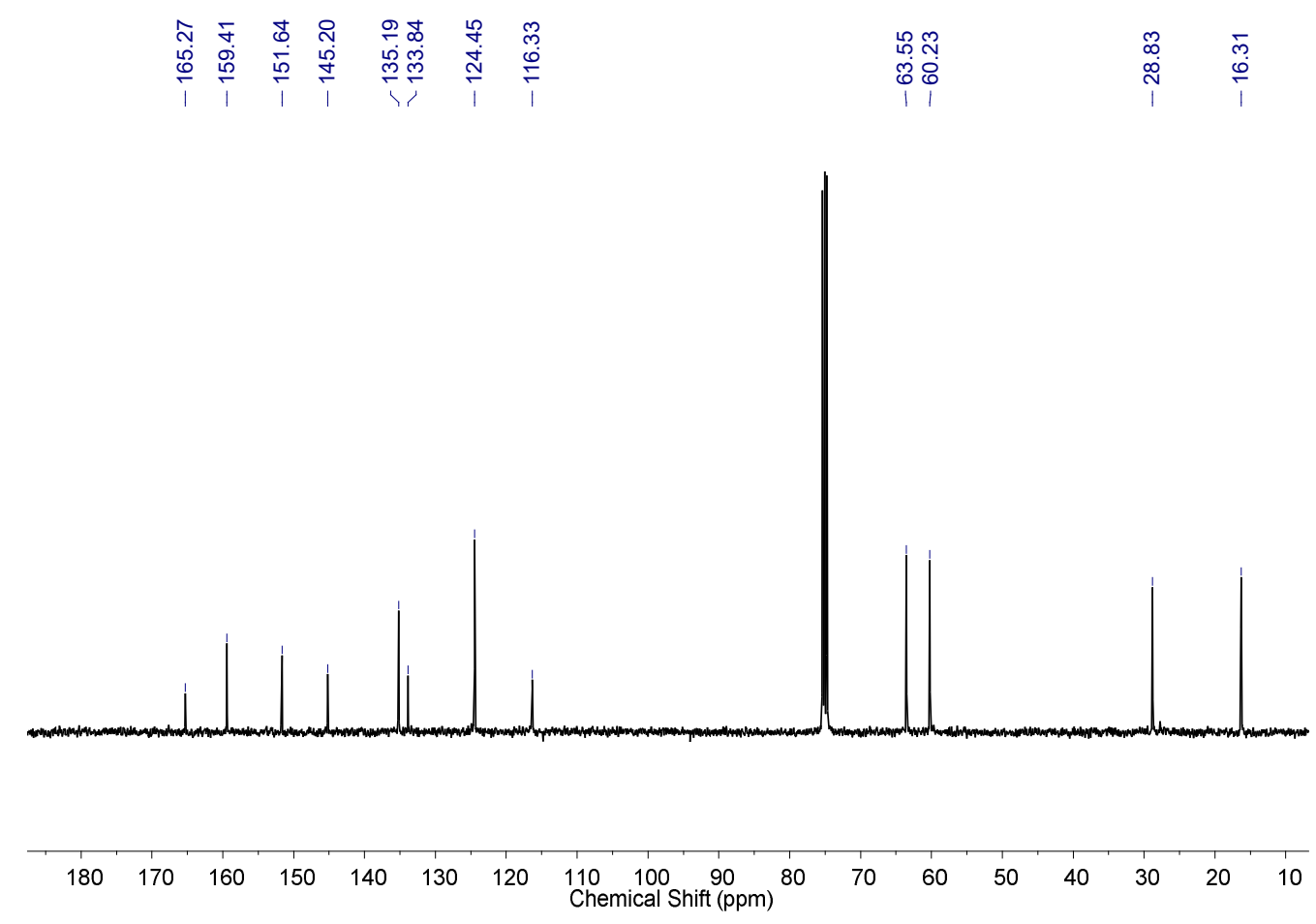

Figure S8. ${ }^{13} \mathrm{C}$ NMR spectrum of MA4 in $\mathrm{CDCl}_{3}$.

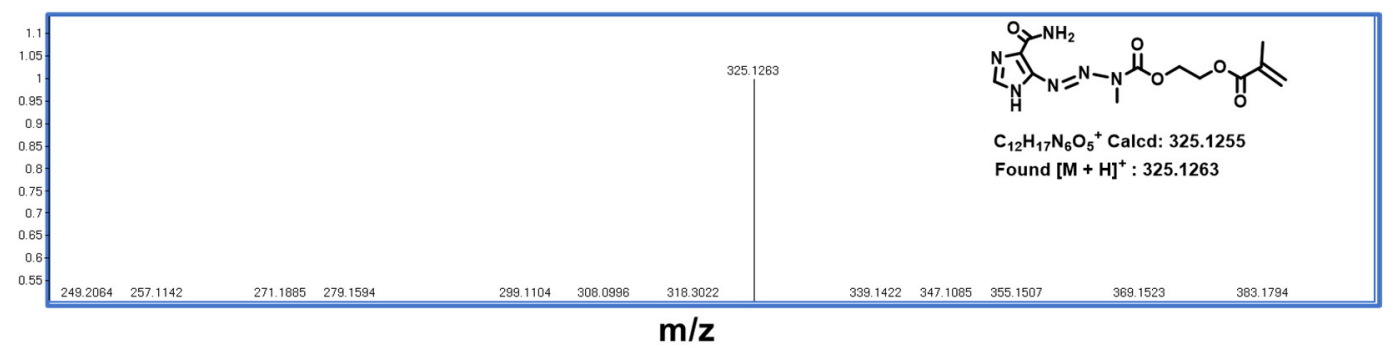

Figure S9. Q-TOF LC/MS spectrum of MA4 in MeOH. 


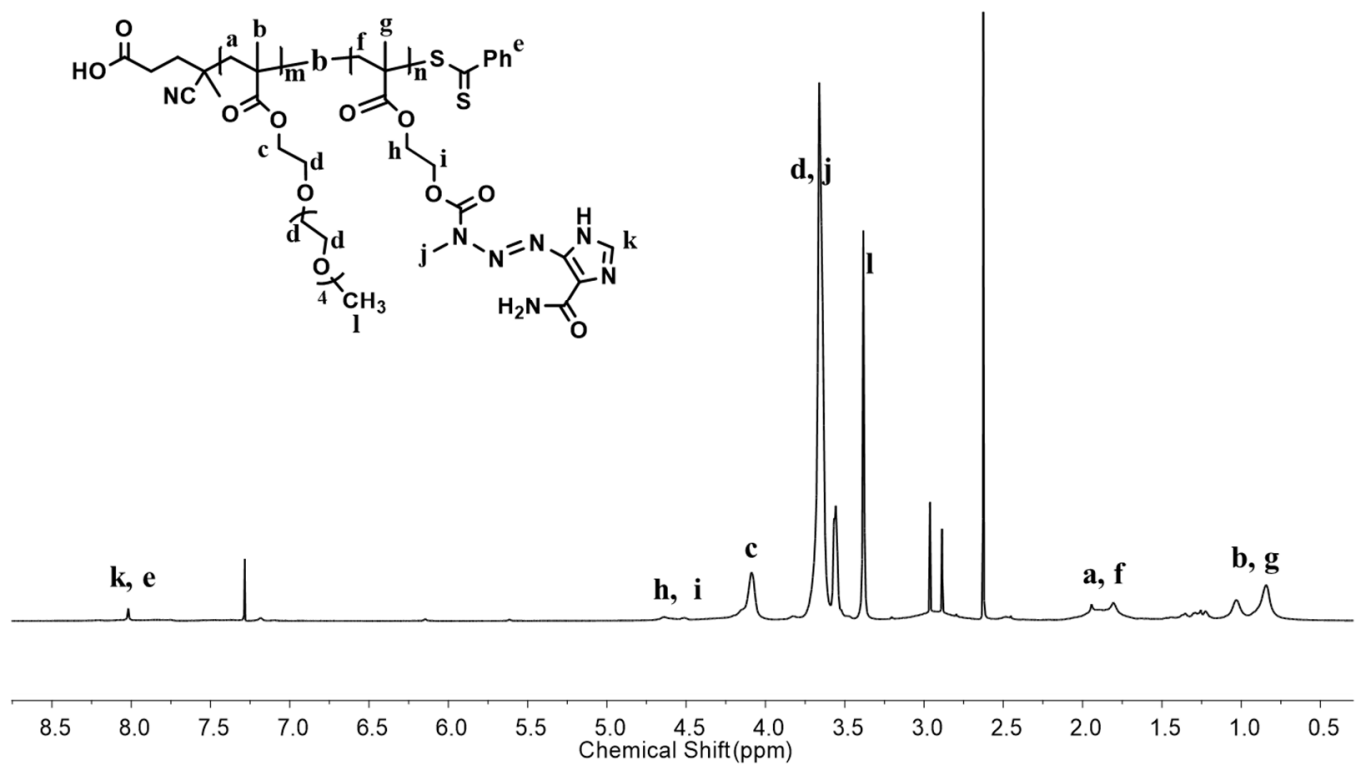

Figure S10. ${ }^{1} \mathrm{H}$ NMR spectrum of $\mathrm{P} 2$ in $\mathrm{CDCl}_{3}$.

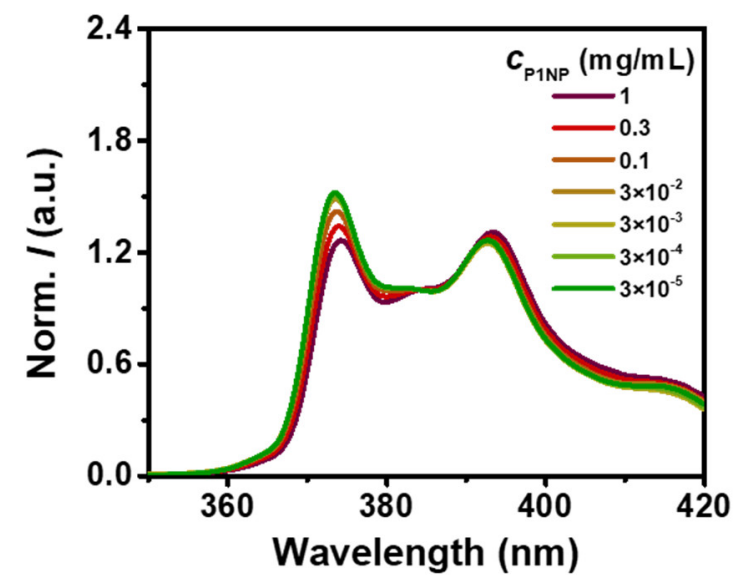

Figure S11. Emission spectra of pyrene in different concentrations of P1NP. 


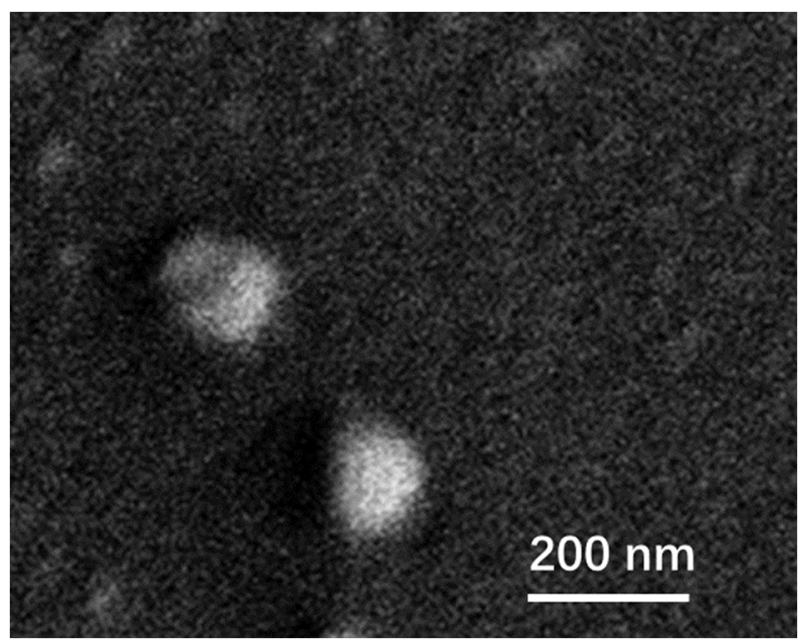

Figure S12. HR-SEM image of P1NP. Scale bar, $200 \mathrm{~nm}$.

(a)

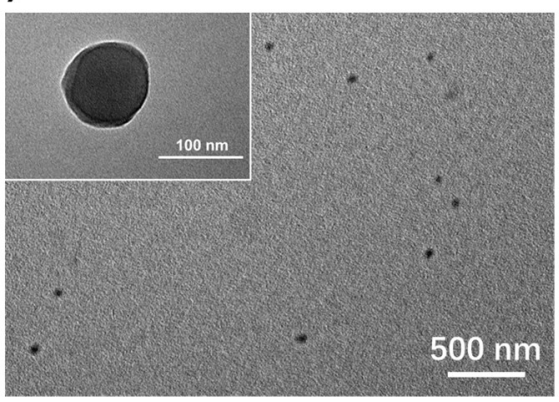

(b)

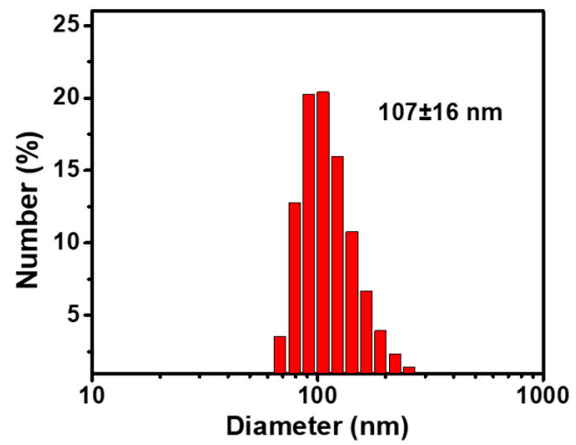

Figure S13. (a)TEM image of P2NP. Inset: enlarged TEM image. (b) DLS analysis of P2NP in PBS buffer.

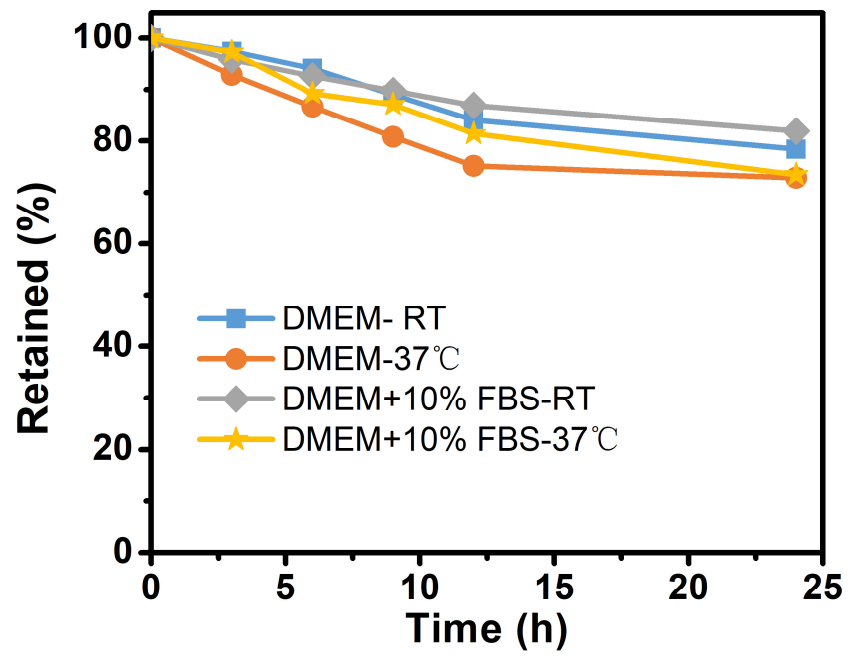

Figure S14. Time-dependent percentages of remaining P1NP under different conditions. 


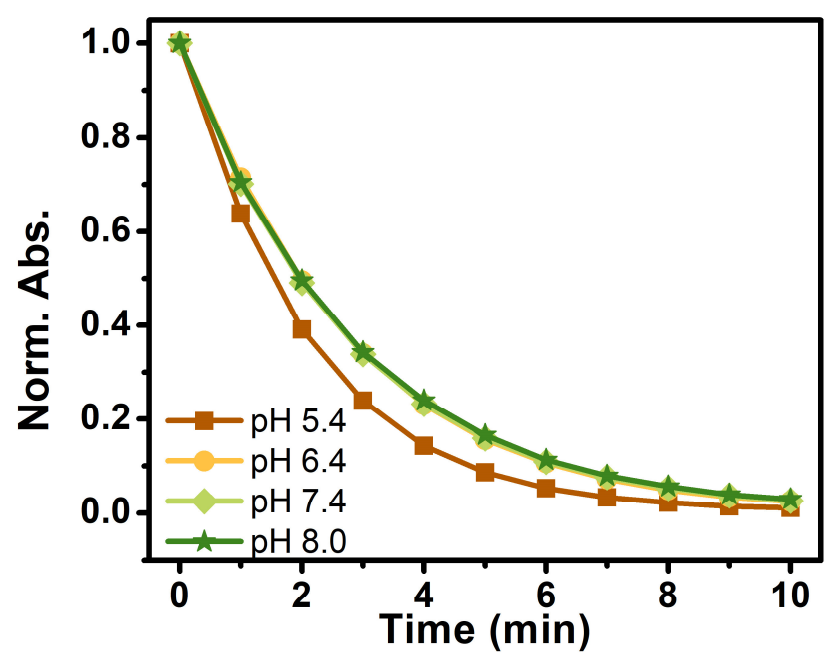

Figure S15. The pH-dependent $A_{320}$ of MTIC at $37^{\circ} \mathrm{C}$.

(a)

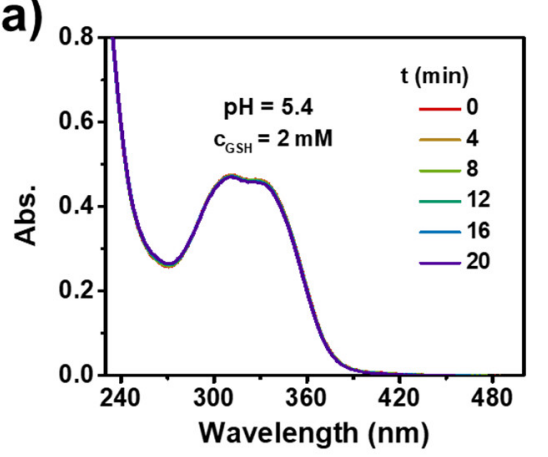

(c)

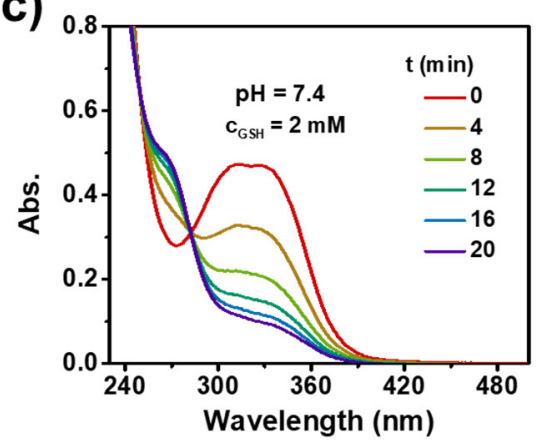

(b)

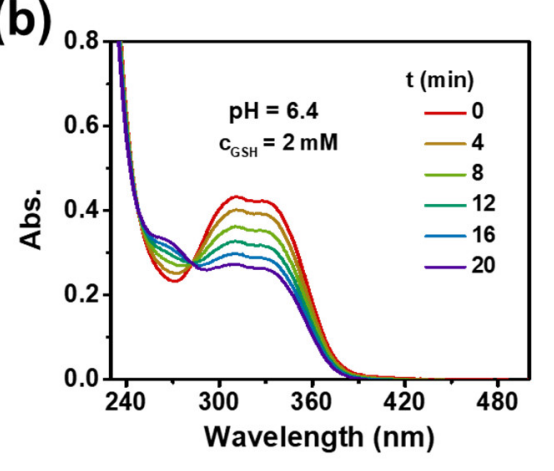

(d)

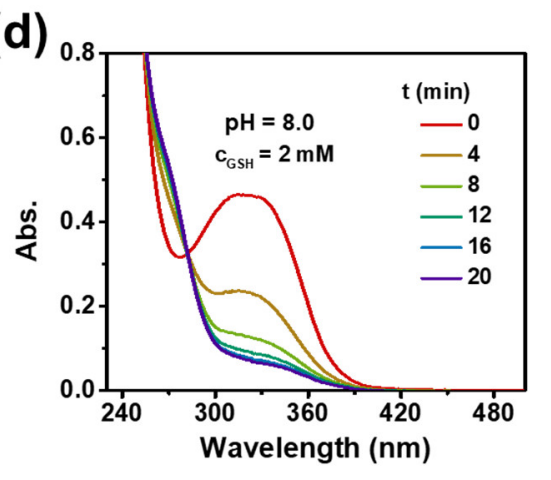

Figure S16. The changes of UV/Vis absorption spectra of P1NP in the presence of 2 mM GSH at $37{ }^{\circ} \mathrm{C}$ and varied $\mathrm{pH}$ : (a) $\mathrm{pH} 5.4$, (b) $\mathrm{pH}$ 6.4, (c) $\mathrm{pH} 7.4$, and (d) $\mathrm{pH} 8.0$. 

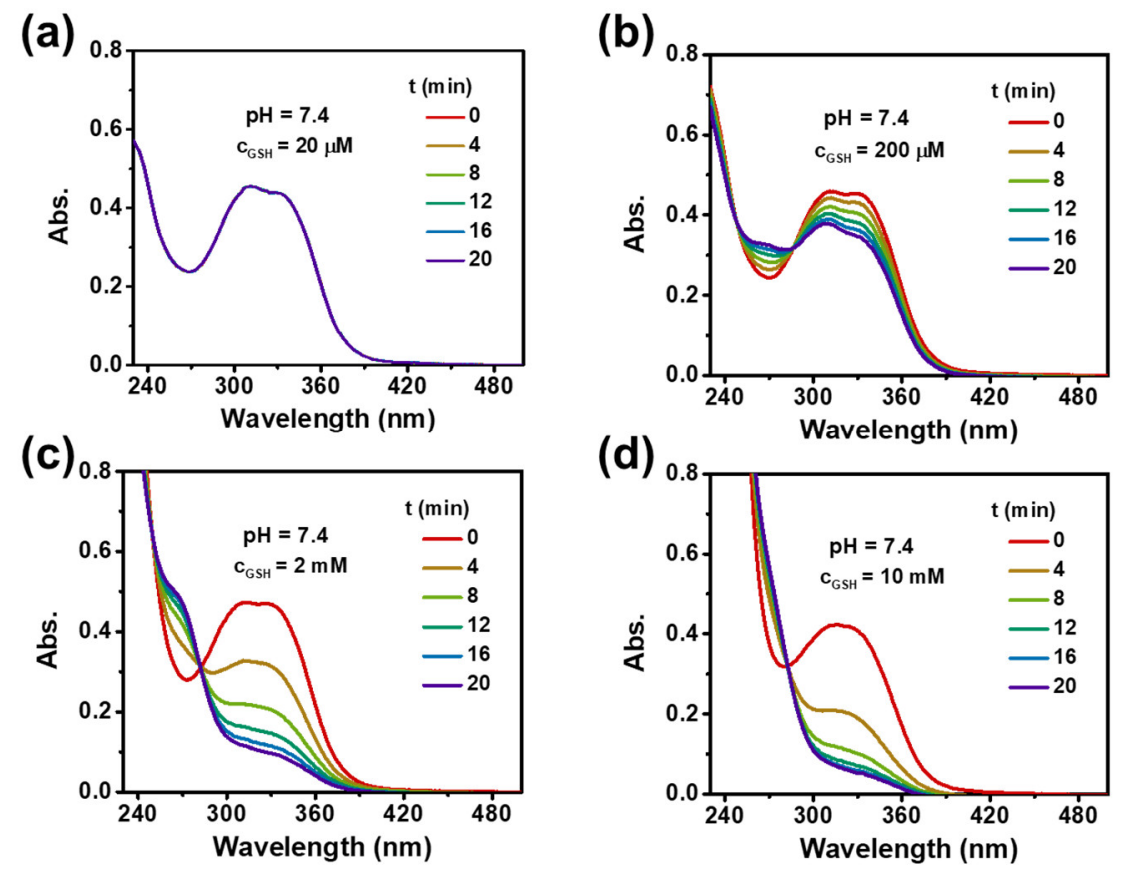

Figure S17. The changes of UV/Vis absorption spectra of P1NP in PBS ( $\mathrm{pH} 7.4)$ at $37{ }^{\circ} \mathrm{C}$ in the presence of varied concentrations of GSH: (a) $0.02 \mathrm{mM}$, (b) $0.2 \mathrm{mM}$, (c) 2 $\mathrm{mM}$, and (d) $10 \mathrm{mM}$.
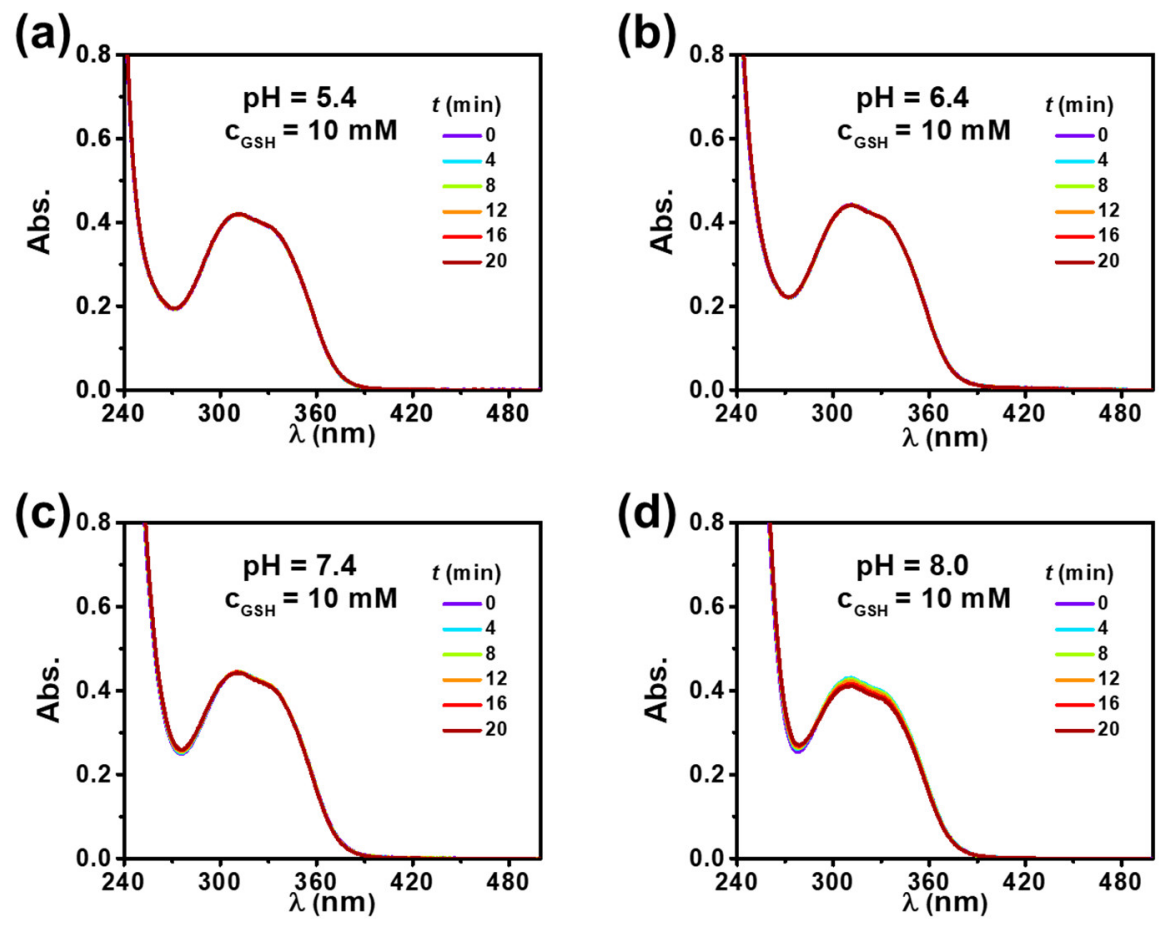

Figure S18. The changes of UV/Vis absorption spectra of P2NP in the presence of 10 mM GSH at $37^{\circ} \mathrm{C}$ and varied $\mathrm{pH}$ : (a) $\mathrm{pH}$ 5.4, (b) $\mathrm{pH}$ 6.4, (c) $\mathrm{pH} 7.4$, and (d) $\mathrm{pH} 8.0$. 


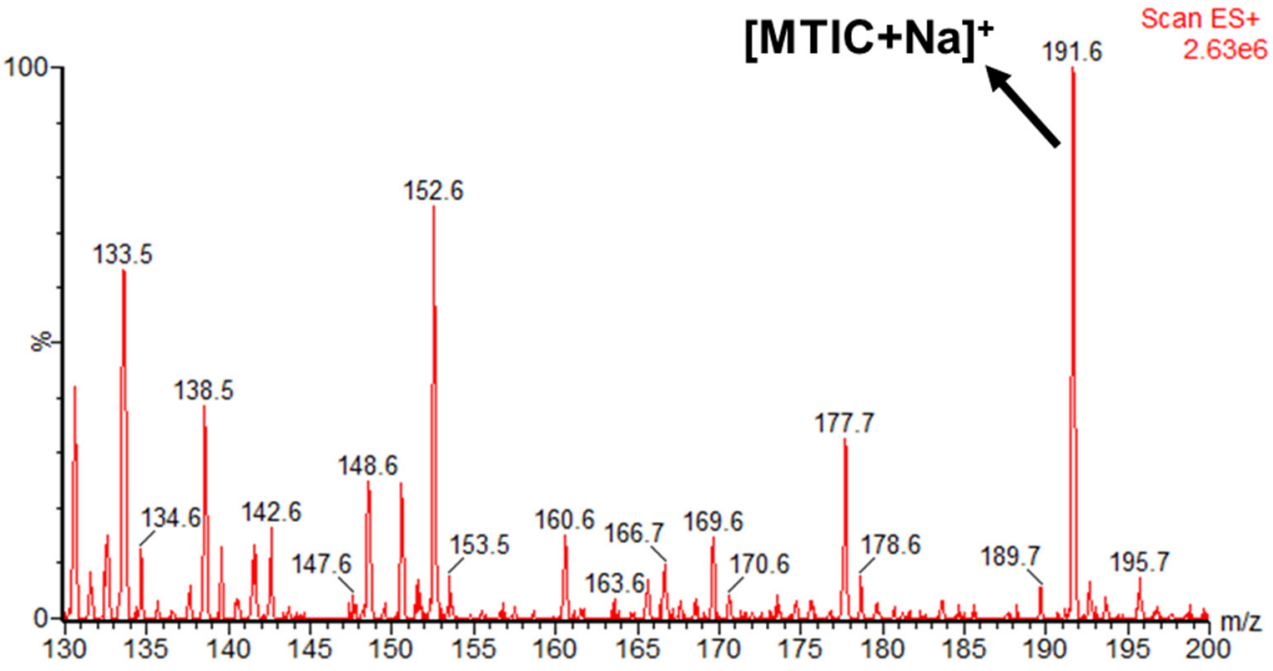

Figure S19. Mass spectrum of UPLC-analyzed sample that was collected from the filtrate at a retention time of $0.36 \mathrm{~min}$ in the $320 \mathrm{~nm}$ PDA channel. The filtrate was obtained by ultracentrifugation of P1NP $\left(C_{\mathrm{MTIC}}=100 \mu \mathrm{M}\right)$ after light irradiation.

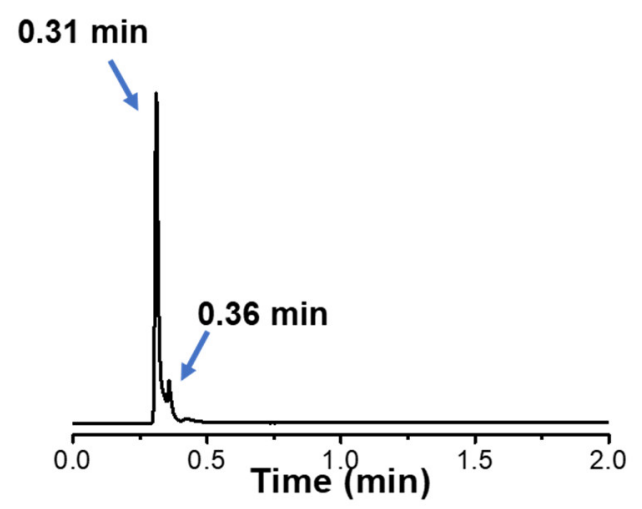

Figure S20. UPLC analysis of the filtrate of P1NP $(100 \mu \mathrm{M})$ after light irradiation, detected in a PDA channel $\left(\lambda_{270} \mathrm{~nm}\right)$. AIC and MTIC appeared at a retention time of 0.31 and $0.36 \mathrm{~min}$, respectively. 


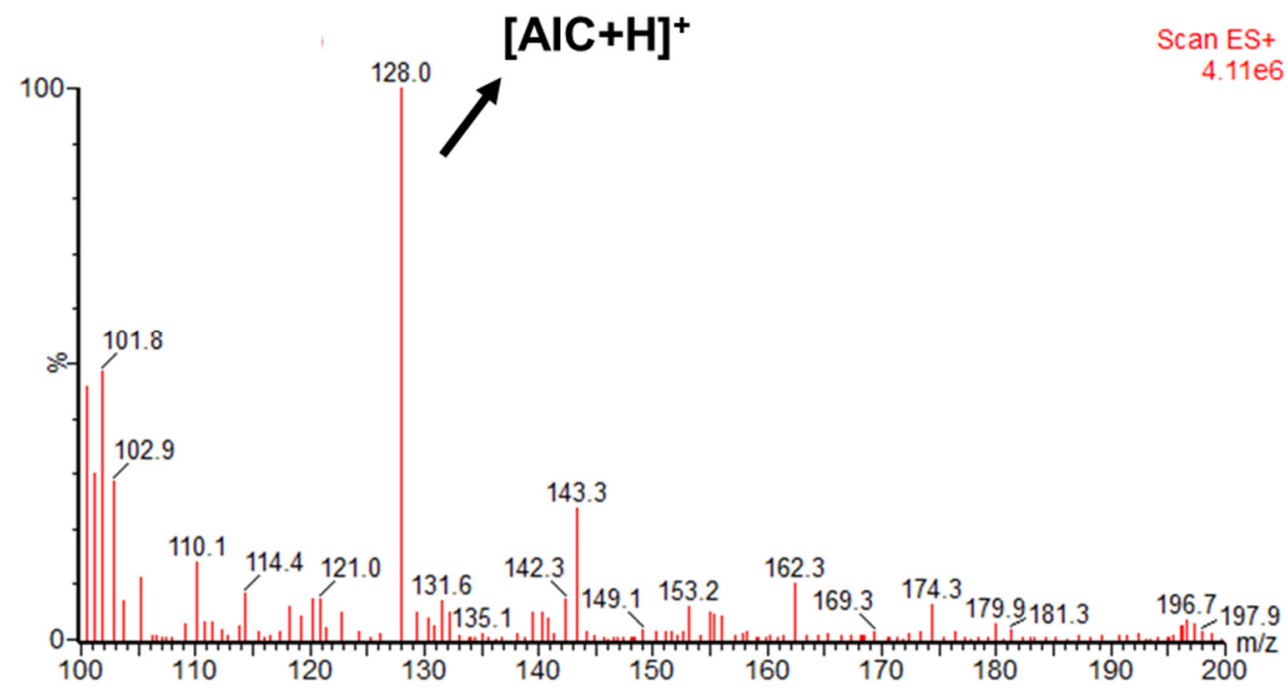

Figure S21. Mass spectrum of UPLC-analyzed sample that was collected from the filtrate at a retention time of $0.31 \mathrm{~min}$ in the $270 \mathrm{~nm}$ PDA channel. The filtrate was obtained by ultracentrifugation of P1NP $\left(C_{\mathrm{MTIC}}=100 \mu \mathrm{M}\right)$ after light irradiation.

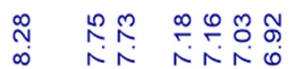

i in nitio<smiles></smiles>

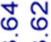

लं

הุก

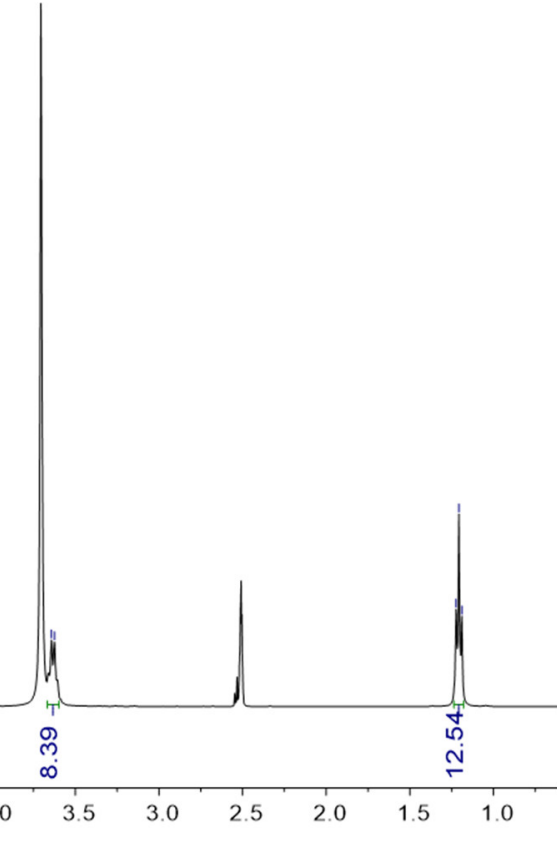

Figure S22. ${ }^{1} \mathrm{H}$ NMR spectrum of SRB-Cl in DMSO-d 6 . 


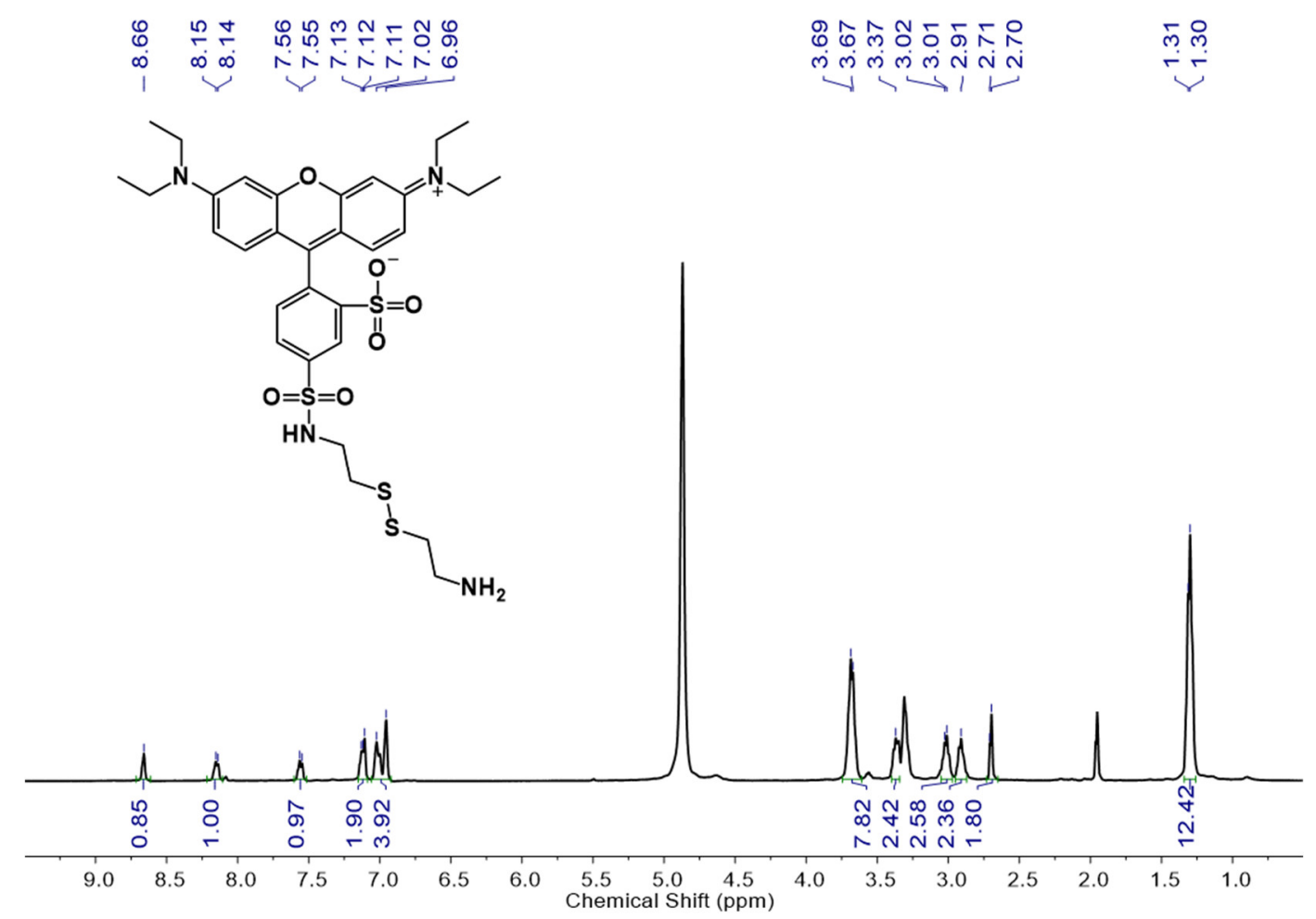

Figure S23. ${ }^{1} \mathrm{H}$ NMR spectrum of $\mathrm{SRB}-\mathrm{NH}_{2}$ in MeOD- $\mathrm{d}_{4}$.

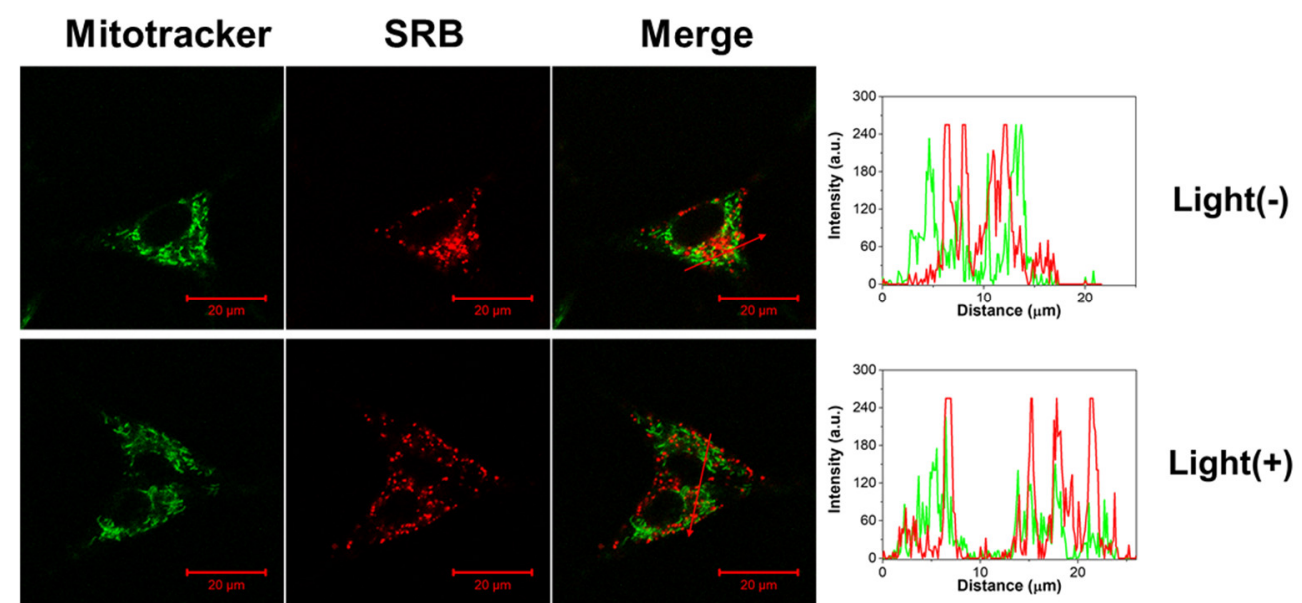

Figure S24. CLSM images of Rhop1NP-treated U87MG cells with or without light irradiation. The mitochondria were stained by Mito Tracker Green $\left(\lambda_{E x}=488 \mathrm{~nm}\right)$. Scale bar, $20 \mu \mathrm{m}$. 


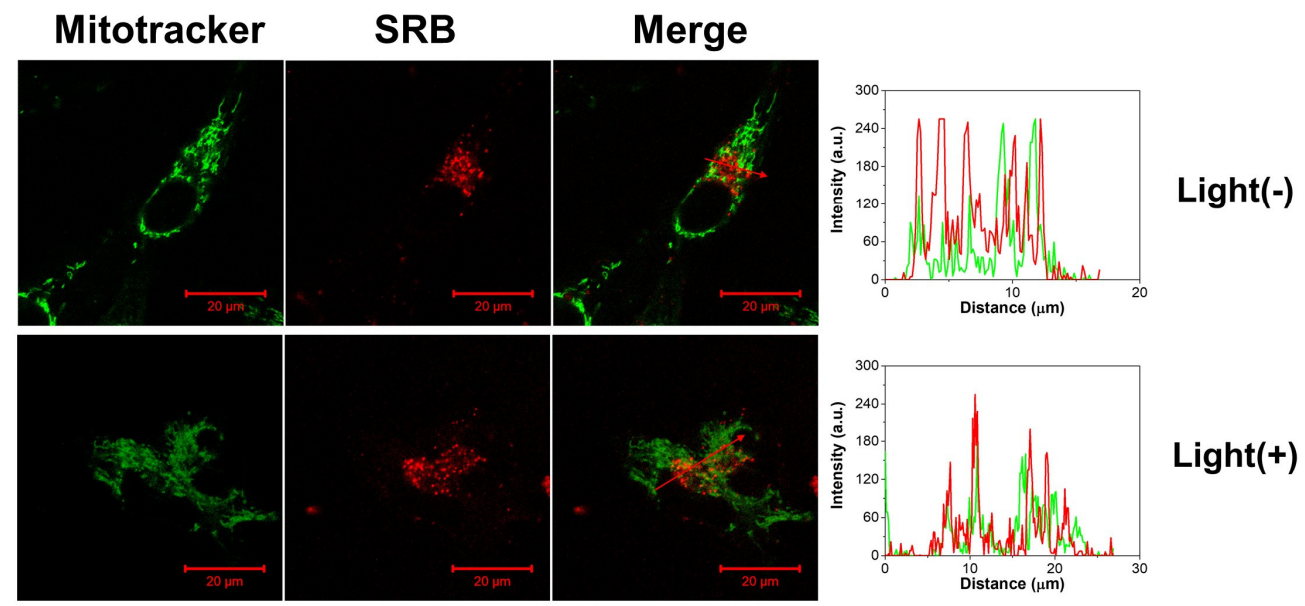

Figure S25. CLSM images of Rhop1NP-treated T98G cells with or without light irradiation. The mitochondria were stained by Mito Tracker Green $\left(\lambda_{E x}=488 \mathrm{~nm}\right)$. Scale bar, $20 \mu \mathrm{m}$.

\section{REFERENCES}

(1) Baig, G. U.; Stevens, M. F. G. Antitumor Imidazotetrazines. Part 12. Reactions of Mitozolomide and its 3-Alkyl Congeners with Oxygen, Nitrogen, Halogen, and Carbon Nucleophiles. J. Chem. Soc., Perkin Trans. 1 1987, 665-670.

(2) Zuwala, K.; Smith, A. A. A.; Tolstrup, M.; Zelikin, A. N. HIV Anti-latency Treatment Mediated by Macromolecular Prodrugs of Histone Deacetylase Inhibitor, Panobinostat. Chem. Sci. 2016, 7, 2353-2358.

(3) Deng, Z.; Yuan, S.; Xu, R. X.; Liang, H.; Liu, S. Reduction-Triggered Transformation of Disulfide-containing Micelles at Chemically Tunable Rates. Angew. Chem. Int. Ed. 2018, 57, 8896-8900.

(4) H. Yang, S. Vasudevan, C. O. Oriakhi, J. Shields, R. G. Carter, Scalable Synthesis of Lissamine Rhodamine B Sulfonyl Chloride and Incorporation of Xanthene Derivatives onto Polymer Supports. Synthesis 2008, 6, 957-961

(5) Mehlich, J.; Ravoo, B. J. Click Chemistry by Microcontact Printing on SelfAssembled Monolayers: A Structure-reactivity Study by Fluorescence Microscopy. Org. Biomol. Chem., 2011, 9, 4108-4115. 